\title{
Estimation of limit of detection of Salmonella typhimurium in artificially contaminated chicken meat by cultured-based and polymerase chain reaction techniques
}

\author{
Y.H. Sharif ${ }^{\circ}$ and B.A. Tayeb \\ Department of Laboratory, Veterinary Directorate in Duhok Province, Duhok, Iraq
}

\author{
Article information \\ Article history: \\ Received June 13, 2020 \\ Accepted August 3, 2020 \\ Available online October 1, 2021

\section{Keywords:} \\ Artificially contamination \\ Chicken meat \\ Limit of detection \\ PCR \\ Salmonella typhimurium
}

\section{Correspondence:}

Y.H. Sharif

drysf2020@gmail.com

\begin{abstract}
The objective of this study was to develop Polymerase Chain Reaction (PCR) procedure for detection of Salmonella Typhimurium in artificially contaminated chicken meat. The experiments were conducted with various dilutions of Salmonella Typhimurium reference the American Type Culture Collection ATCC (ATCC13311 ${ }^{\mathrm{TM}} 4.4^{*} 10^{7}$ ) High concentration $4.4 * 10^{3}$ Colony Forming Units $(\mathrm{CFU}) / \mathrm{ml}$, low concentration $4.4 * 10^{2}$ $\mathrm{CFU} / \mathrm{ml}$, very low concentration $4.4^{*} 10^{1} \mathrm{CFU} / \mathrm{ml}$ inoculated in chicken meat, in order to determine limits of detection (LOD), optimum incubation times 18 to 20 hours of preenrichment in Buffered Peptone Water (BPW 1\%). Hence, cultural methods and DNA extraction were performed according to kits instruction. The microbiological cultural test was capable to detect $1.76 \mathrm{CFU} / \mathrm{mL}$, whereas PCR examination was able to detect 0.18 $\mathrm{CFU} / \mathrm{ml}$ of initial dilution of Salmonella Typhimurium inoculated in chicken meat. Interestingly, the results were achieved in a less time period than that of classical culture. The PCR technique is beneficial in the methodology for detection of Salmonella in chicken meat.
\end{abstract}

DOI: 10.33899/ijvs.2020.127328.1496, CAuthors, 2021, College of Veterinary Medicine, University of Mosul.

This is an open access article under the CC BY 4.0 license (http://creativecommons.org/licenses/by/4.0/).

\section{Introduction}

Salmonella is one of the most important pathogen that can infect human through ingestion of contaminated food with a sub-classification of more than 2500 serovars including Typhimurium related to foodborne salmonellosis in human $(1,2)$. This infection can be harsh particularly in immunosuppressive people like youngest or elderly people. It is estimated that the possible infection dose in the healthy individuals is very low and between 105 to 107 colonies of the bacterium (3). In many different developing countries, the numbers of food-borne infection cases are increasing. Almost all of them connected with the consumption of contaminated chicken products. In a survey performed by the Centre of Diagnostics and Research in Avian Pathology (CDPA) on a total of 1300 carcasses of chicken that tested for salmonella showing that the percentage of contaminated chicken meat was more than $17 \%(4,5)$. In addition, other prospective study has confirmed that the contamination rate of this pathogen was about $10 \%$ (6). It is crucial to take actions for prevention of getting this foodborne infection based on standard quality control and detection techniques, so that improvement of food safety technologies related to salmonellosis. Nowadays, the cultured-based detection procedure is still used as a main way for the detection of salmonella in food products. In addition, salmonella should not be detected in $25 \mathrm{~g}$ of food samples according to a number of governmental standard regulations and recommendations (7). However, this kind of techniques could be time consuming and not sensitive enough to detect low-abundance of the level of contamination (8). New methods have been introduced to get better results and get more advantages than traditional ways. PCR is a major molecular biology assay and considered as a novel and sensitive technique in the field of laboratory diagnostics (9). This new technology allows detecting of various food- 
borne pathogens including salmonella in very low bountiful $(10,11)$. However, the PCR assay has some drawback as false-positive may occur. Nevertheless, PCR can minimize the time for detection and identification of food-borne pathogens in food products. It is well known that the $\operatorname{InvAsion}$ Protein A gene (InvA) has a unique sequence encoding for salmonella spp. (12). Therefore, a pair of primers was used in the current study that specific for detection of the gene InvA.

The aim of the present study is to determine the LOD 50 (contamination level at which $50 \%$ of the samples are found positive) of Salmonella Typhimurium in artificially contaminated chicken meat and to compare the detection limits from the results of both cultured-based traditional and PCR assays.

\section{Materials and methods}

\section{Bacterial strains and inoculation of food matrix}

Aliquots of Salmonella Typhimurium ATCC strain 13311 CAT. No. 7E21 and Escherichia coli (E. coli) ATCC strain 51813 were used as reference strains in this study. Salmonella Typhimurium and the non-Salmonella bacterial strains information used in this study. These strains were cultivated into Tryptone Soya Broth (TSB, HIMEDIA, India) at $37^{\circ} \mathrm{C}$ for 24 hours for confluent growth.

\section{Sample preparation}

One hundred twenty samples of chicken meat were used in this research for artificial contamination. From each sample, 25 grams were weighed in sterile bags (Seward Medical Stomacher ${ }^{\circledR} 400$ sterile bags). To this, $225 \mathrm{~mL}$ of BPW $1 \%$ were added and homogenized in a Stomacher (Laboratory Blender Stomacher 400, Seward Medical, UK) for about 30 seconds. This mixture was then inoculated with $1 \mathrm{~mL}$ of high concentration of bacterial load $4.4^{*} 10^{3}$ $\mathrm{CFU} / \mathrm{ml}$ and low concentration of bacterial load $4.4^{*} 10^{2}$ $\mathrm{CFU} / \mathrm{ml}$ and very low concentration of bacteria $4.4^{*} 10^{1}$ $\mathrm{CFU} / \mathrm{ml}$ of dilution of bacterial strains (13).

\section{Culture method}

After 18 hrs. of pre-enrichment in Buffered Peptone water (BPW), isolation of Salmonella Typhimurium was conducted according to 6579-1:2017 procedure $(13,14)$.
Briefly, $0.1 \mathrm{~mL}$ from the pre-enrichment solution was transferred separately into two different tubes containing 10 $\mathrm{mL}$ of Rappaport-Vassiliadis broth (Merck, USA) and into $1.0 \mathrm{~mL}$ of Mueller Kauffman Tetrathionate Novobiocin Broth Base for selective enrichment and incubated at $41.5^{\circ} \mathrm{C}$ and $37^{\circ} \mathrm{C}$ for $21 \mathrm{hrs}$. respectively. One loopful of broth cultures were streaked onto Xylose Lysine Deoxycholate (XLD) agar (Lab-M, UK) and CHROMagar (Oxoid, UK) and incubated for $21 \mathrm{hrs}$. at $37^{\circ} \mathrm{C}$. Purification of colonies was done on nutrient agar. In addition, the suspected colonies were further confirmed by using biochemical and serological tests according to ISO 65791:2017.

\section{DNA extraction by lysis buffer}

The extraction of DNA from S. Typhimurium was adapted from a previous study (15). One $\mathrm{ml}$ of broth from the pre-enrichment were transferred into a tube and centrifuged at $10000 \mathrm{rpm}$ for $5 \mathrm{~min}$ and the supernatant was discarded. The pellet was suspended in $500 \mathrm{~mL}$ of lysis buffer (containing $0.1 \mathrm{Mm}$ Ethylenediaminetetraacetic acid (EDTA), $50 \mathrm{Mm}$ Tris-Hcl, PH 8.0, $1 \%$ TRITON-X-100, $0.5 \%$ Tween-20) and vortexed for 10 second. The samples were placed on a thermal block (Multi-Blok Heater, Baxter, and EUA) at $95^{\circ} \mathrm{C}$ for $10 \mathrm{~min}$. The mixture was centrifuged for $20 \mathrm{~s}$ at $5000 \mathrm{rpm}$ and the supernatant was stored at $18^{\circ \circ} \mathrm{C}$ for 10 minutes. Finally, the PCR assay was done at the same day of extraction.

\section{PCR procedure}

PCR was carried out according to kit manufacture instructions. The procedure was adopted from a previous work that studied on more than 600 strains of salmonella in chicken (15). The thermal cycler that used in the current study was set in an Applied Bio-systems ABI GeneAmp PCR System 9700 thermal cycler. Samples were denatured at $94^{\circ} \mathrm{C}$ for $5 \mathrm{~min}$ as pre-holding step. Thirty-five cycles of amplification were run for $30 \mathrm{~s}$ at $94^{\circ} \mathrm{C}, 30 \mathrm{~s}$ at $54^{\circ} \mathrm{C}$ and 30 $\mathrm{s}$ at $72^{\circ} \mathrm{C}$, with the final extension continuing for $7 \mathrm{~min}$. Twenty-five microliter aliquots of the reaction mixtures were electrophoresed through $1.5 \%$ agarose gel and fragments were revealed by staining with DNA safe dye (16) (Table 1).

Table 1: Primers that are used in this verification procedure for S. typhimurium

\begin{tabular}{lcc}
\hline S. typhimurium primer & Length & Primer sequence $5^{\prime} \rightarrow 3^{\prime}$ \\
\hline InvA forward & $22 \mathrm{bp}$ & CGG TGG TTT TAA GCG TAC TCT T \\
InvA reverse & $21 \mathrm{bp}$ & CGA ATA TGC TCC ACA AGG TTA \\
\hline
\end{tabular}

\section{Statistical analysis}

For the performance of a qualitative method, sensitivity, specificity and LOD 50 were calculated. LOD50 was calculated using a program in Excel as described in ISO that is freely available on the internet (17). The calculation of sensitivity and specificity (\%) is described below. Sensitivity $=(\mathrm{N}+/ \mathrm{N}) * 100$, where $N+$ is the number of positive results at a low/high contamination level of the pathogen and $N$ is the total number of analyzed samples at this level. Specificity $=(\mathrm{N}-/ \mathrm{N}) * 100$, where $N$ - is the number 
of negative results at blank level and $N$ is the total number of analyzed samples at this level.

\section{Results}

\section{Culture methods}

It can be seen that this method was not able to recover very low concentration contaminated chicken (i.e less than $1 \mathrm{CFU} / \mathrm{ml}$ ). However, this technique was able to detect 38 samples out of $40(95 \%)$ from low concentration and 40 out of $40(100 \%)$ from high concentration $(10-50 \mathrm{CFU} / \mathrm{ml})$. There were no false positives recorded in this experiment (Table 2). When inoculated on XLD agars, the different concentration showed the different recovery concentration growth of the pathogen (Figure 1).

\section{Molecular detection}

The sensitivity of the primers is $100 \%$ when the load of the pathogen in more than $1-5 \mathrm{CFU} / \mathrm{ml}$ in a sample and $75 \%$ when there is less than $1 \mathrm{CFU} / \mathrm{ml}$ (Table 3). The specificity of primer pairs used in the current study showed through the results of the PCR technique in detection of particular organisms in chicken. The specificity of the primers was $100 \%$ as the negative samples were nonedetectable. All the samples that inoculated with high concentration of bacterial load were detectable by this particular set of primers. In addition, all the positive samples were analyzed and confirmed as bands by using gel electrophoresis from a composition of $1.5 \%$ of agarose. According to the position of this gene and detection primers, the band should be appearing around $284 \mathrm{bp}$ (Figure 2).

Table 2: Cultured-based method results show the sample number and inoculation contamination level of S. typhimurium

\begin{tabular}{ccccc}
\hline No & Chicken samples & Contamination level & Positive reference & Negative reference \\
\hline 1 & 40 & Less than $1 \mathrm{CFU} / \mathrm{mL}$ & $0 / 40(0.0 \%)$ & Not detected \\
2 & 40 & $1-5 \mathrm{CFU} / \mathrm{mL}$ & $38 / 40(95 \%)$ & Not detected \\
3 & 40 & $10-50 \mathrm{CFU} / \mathrm{mL}$ & $40 / 40(100 \%)$ & Not detected \\
\hline
\end{tabular}

Table 3: PCR results show the sample number and inoculation contamination level of S. typhimurium

\begin{tabular}{ccccc}
\hline No. & Chicken samples & Contamination level & Positive reference & Negative reference \\
\hline 1 & 40 & Less than $1 \mathrm{CFU} / \mathrm{mL}$ & $31 / 40(75 \%)$ & Not detected \\
2 & 40 & $1-5 \mathrm{CFU} / \mathrm{mL}$ & $40 / 40(100 \%)$ & Not detected \\
3 & 40 & $10-50 \mathrm{CFU} / \mathrm{mL}$ & $40 / 40(100 \%)$ & Not detected \\
\hline
\end{tabular}
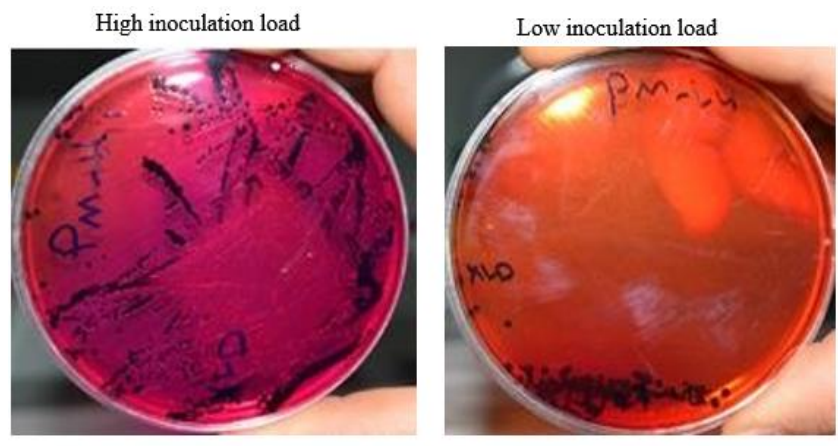

Figure 1: High and low bacterial inoculations on XLD agars. Typical colonies are red with black centers.

\section{Limit of detection}

Estimation the detection limit of S. typhimurium was determined according to previous interlaboratory data that are available online. In that program, the contamination level of each test portion of the samples has to be provided in CFU/g or CFU/ml. Simply, the lower inoculation levels of each test samples were divided by the total amount of test portion in a tube. In fact, the current study used $25 \mathrm{~g}$ of the sample plus $225 \mathrm{ml}$ of BPW and the total amount in a bottle was $250 \mathrm{~g}$. hence, low inoculation level for the traditional method and PCR assay that were detectable was $4.4^{*} 10^{2} \mathrm{CFU} / \mathrm{ml}$ and $4.4^{*} 10^{1} \mathrm{CFU} / \mathrm{ml}$, respectively. If these numbers divided by 250 , there will be 1.76 and $0.18 \mathrm{log}$ $\mathrm{CFU} / \mathrm{ml}$ for cultured-based traditional and PCR methodologies, respectively.

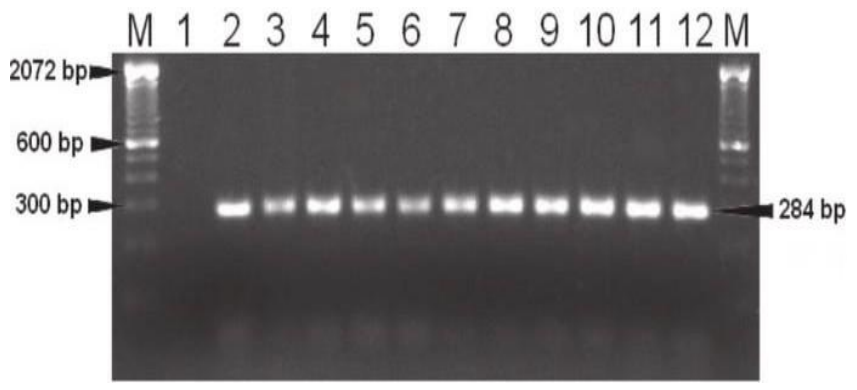

Figure 2: Gel electrophoresis for detection of InvA gene at 284 bp encoding Salmonella Typhimurium in artificially contaminated chicken meat. Image of PCR product running on $1.5 \%$ of agarose gel for 90 minutes at $120 \mathrm{~V}$. M: DNA marker, Lane 1: Negative control, Lanes 2-12: Artificially positive samples. 


\section{Discussion}

According to the ISO 6579-1:2017, the detection limit is 0.22-0.72 log CFU/ml for chicken meat (18). In the current research, the LOD of $0.39 \log \mathrm{CFU} / \mathrm{ml}$ was scored for artificially contaminated chicken meat which is very close to the reference method. AENOR 16140, laboratory validation has stated that reference method for cultural growth with limit of detection of 0.40-1.02 CFU/g (19). In this particular aspect, these results are in accordance with those from AENOR 16140, laboratory validation method for detection of Salmonella. The findings of the study showed more than $95 \%$ of artificially contaminated sample were detected for the presence of low bacterial concentration in range of $1-5 \mathrm{CFU} / \mathrm{ml}$. Not surprisingly, all samples were detected for the higher load of bacterial concentration in conventional methods with the detection limit of $100 \%$. In the current findings, a pair of primers was applied to detect salmonella typhimurium serovar simultaneously using conventional PCR. The pair of the primers used to find Salmonella at genus level codifies the gene InvA that is widely distributed in Salmonella spp. $(5,20,21)$. In addition, the reference procedure of the ISO numbered 6579-1:2017 used as a complementary test to PCR for detection the limit of salmonella conducted for all the examined samples.

These assays were established using artificially contaminated chicken meat samples after 16 hours of preenrichment and using the bacterial DNA extraction kit. In the current study, the PCR assay was able to detect a cell suspension of $1 \mathrm{CFU} / \mathrm{ml}$ (about $1 \mathrm{CFU}$ per reaction) with a probability of $75 \%$ and a cell suspension of $10^{1} \mathrm{CFU} / \mathrm{ml}(5$ CFU per reaction) with a probability of $100 \%$. These findings are in agreement with a previous research (22) where it found (5 CFU per reaction) with a probability of $70 \%$ and a cell suspension of (50 CFU per reaction/ml) with a probability of $100 \%$. In terms of pre-enrichment step, the duration was approximately $16 \mathrm{hrs}$. and this was sufficient for the recovery and subsequent multiplication of sub-lethally injured Salmonella to be in detectable levels in the real-time PCR. A previous study has observed that the duration of $20 \mathrm{hrs}$. as a pre-enrichment step is sufficient for recovery of Salmonella spp. (22).

\section{Conclusion}

Fast detection of pathogens in food products is critical for the diagnosis of food poisoning and monitoring of food safety. Our studies represent the first report of using enrichment culture- based and PCR methods to detect LOD of artificially inoculated Salmonella Typhimurium in chicken in Duhok city of Iraq. The molecular detection method is efficient and reliable with higher sensitivity and specificity when compared to microbiological culture.

\section{Acknowledgements}

We would like to express our sincere gratitude to the Laboratory Department at the Veterinary Directorate in Duhok province for providing the laboratory facility.

\section{Conflict of interest}

Authors declare no conflict of interest.

\section{References}

1. Popoff MY, Bockemuhl J, Gheesling LL. Supplement 2001 (no. 45) to the Kauffmann-White scheme. Res Microbiol. 2003;(154):173-174. DOI: $10.1016 / \mathrm{S} 0923-2508(03) 00025-1$

2. Jesny B, Sabri II, Al-Sultan K, Sherly P, Mohammed JS. Pathogenesis of Salmonella enterica serovar albany in experimental infected SPF BALB/c Mice. Iraqi J Vet Sci. 2020;34(2):339-344. DOI: 10.33899/ijvs.2019.126269.1282

3. Varnam AH, Evans MG. Foodborne pathogens. An illustrated text. St. Louis: Mosby Year Book; 1991.

4. Jameel HA, Mohammed MJ, Mahdi MS, Thalj KM. Physiological effects of lactic acid bacteria against melamine induced toxicity in female albino rats. Iraqi $J$ Vet Sci. 2021;35(1):1-7. DOI: 10.33899/ijvs.2020.126183.1259

5. Todd E. Food for thought: Foodborne Pathogens: An Illustrated Text. CMAJ. 1992;2:214-215. [available at]

6. Shareef AM, Khather ZK. Contamination of the parentstock feed with salmonella in Ninava Government. Iraqi J Vet Sci. 2005;19(2):85-95. DOI: 10.33899 /ijvs.2005.38102

7. Silva DSP, Canato T, Magnani M, Alves J, Hirooka EY, Oliveira TCR, Multiplex PCR for the simultaneous detection of Salmonella spp. and Salmonella enteritidis in food. Int J Food Sci Tech. 2011;46:1502-1507. DOI: 10.1111/j.1365-2621.2011.02646.x

8. Kruger NJ, Buhler C, Ellerbroek L, Appel B, Stingl K, Iwobi AN, Huber I. Limits of control: Crucial parameters for a reliable quantification of viable Campylobacter by Real-Time PCR. PloS One. 2014;9:2. DOI: 10.1371/journal.pone.0088108

9. Paiao FG, Arisitides LGA, Murate LA, Vilas-Boas GT, Vilas-Boas LA, Shimokomaki A. Detection of Salmonella spp, Salmonella enteritidis and typhimurium in naturally infected broiler chickens by a multiplex PCR-based assay. Brazil J Microbiol. 2013;44:37-42. DOI: 10.1590/S1517-83822013005000002

10. Saleh Z, Al-Muhana BM, Hamdan Kh, Jawad MS, Klaif SF. Isolation and identification of Salmonella typhimurium bacteria with detection of type-1 fimbriae coding gene by polymerase chain reaction (PCR) technique. Iraqi J Vet Sci. 2019;33(2):195-199. DOI: 10.33899/ijvs.2019.162961

11. Mahmood MA, Essa MA. Antimicrobial activity of peptides extracted from camels' blood neutrophils against some pathogenic bacteria. Iraqi J Vet Sci. 2021;35(1):33-37. DOI: 10.33899/ijvs.2020.126239.1270

12. Rahn K, De GSA, Clarke RC, McEwen SA, Galán JE, Ginocchio C, Curtiss R. Amplification of an InvA gene sequence of Salmonella typhimurium by polymerase chain reaction as a specific method of detection of Salmonella. Molecul Cellul Probes. 1992;6:271-279. DOI: $10.1016 / 0890-8508(92) 90002-\mathrm{F}$

13. Mooijman KA. The new ISO 6579-1: A real horizontal standard for detection of Salmonella at last!. Food Microbiol. 2018;71:2-7. DOI: 10.1016/j.fm.2017.03.001

14. International Standard Organization (ISO 6579-1), Microbiology of the food chain - Horizontal method for the detection, enumeration and serotyping of Salmonella - Part 1: Detection of Salmonella spp. International Organization for Standardization, Geneva, Switzerland; 2017. 
15. Santos LR, Nascimento VP, Oliveira SD, Flores ML, Pontes AP, Ribeiro AR, Salle CTP. Polymerase chain reaction (PCR) for the detection of Salmonella in artificially inoculated chicken meat. Rev Inst Med Trop Sao Paulo. 2001;43:247-250. DOI: 10.1590/S003646652001000500002

16. Basher HS, Al-Zuhariy MT. Using T cell lymphokines to enhance the immune response against Newcastle disease in vaccinated broiler chickens fed naturally contaminated diet with different mycotoxins. $\begin{array}{llll}\text { Iraqi J Vet Sci. 2020;34(2):427-433. DOI: } & \end{array}$ 10.33899/ijvs.2019.125977.1204

17. International Organization for Standardization (ISO). Microbiology of the food chain, method validation: Protocol for the validation of alternative (proprietary) methods against a reference method Link to $\mathrm{LOD}_{50}$ calculation programmer. [available at]

18. International Organization for Standardization (ISO). Technical Committee ISO/TC 34, Agricultural Food Products, Microbiology of food and animal feeding stuffs: Horizontal method for the detection of Salmonella spp. [available at]

19. International Standard Organization (ISO). Protocol of the alternative method EASY QFast ${ }^{\circledR}$ UNE-EN ISO 16140:2003. microbiology of food and animal feeding stuffs. [available at]

20. Germini A, Masola A, Carnevali P, Marchelli R. Simultaneous detection of Escherichia coli O175:H7, Salmonella spp., and Listeria monocytogenes by multiplex PCR. Food Cont. 2009;20:733-738. DOI: 10.1016/j.foodcont.2008.09.010

21. Sabri BJ, Al-Sultan II, Altaif Kh, Peter S, Saadh MJ. Pathogenesis of Salmonella enterica serovar albany in experimental infected SPF BALB/c Mice. Iraqi J Vet Sci. 2020;34(2):339-344. DOI: $\underline{10.33899 / \text { ijvs.2019.126269.1282 }}$

22. Malorny B, Paccassoni E, Fach P, Bunge C, Martin A, Helmuth R. Diagnostic real-time PCR for detection of Salmonella in food. Appl $\begin{array}{lll}\text { Environ } & \text { Microbiol. 2004;70(12):7046-7052. DOI: }\end{array}$ 10.1128/AEM.70.12.7046-7052.2004

\section{تقدير الحد الأدنى للكشف عن السالمونيلا التايفيوريوم

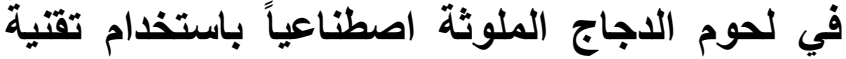 تفاعل سلسلة أنزم البلمرة وبطرق تقليدية}

\author{
يوسف حامد محمد شريف و بزار احمد طيب \\ قسم المختبر، مديرية البيطرة في محافظة دهوك، دهوك، العراق

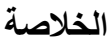

كان الهدف من هذه الدراسة هو تطوير إجراء تفاعل سلسلة أنزم

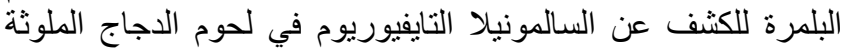

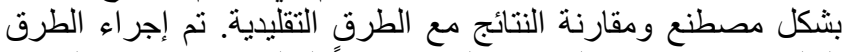

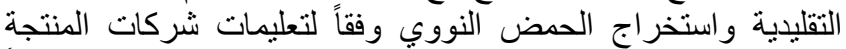

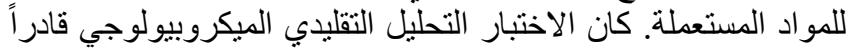
على اكتشاف VT, VT 1, وحدة تشكيل المستعمرة من الجرثوم لكل ملليلتر

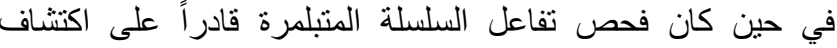

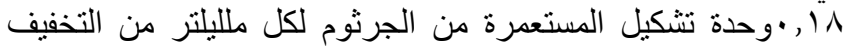

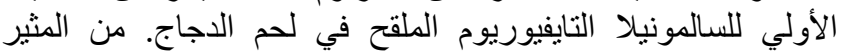
للاهتمام أن النتائج تم تحقيقها في فترة زمنية أقل من الطرق الترف التقليدية

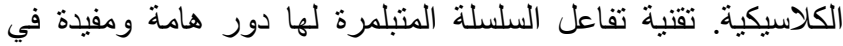
الكثف عن السالمونيلا في لحوم الدجاج. 